\title{
Environmental Monitoring Model of Health, Parasitological, And Colorimetric Conditions of Rivers Bacaxá and Capivari in Rio De Janeiro Lakes Region
}

\author{
Priscila GonçalvesMoura, AntonioNascimento Duarte, LuciannaHelene Silva \\ dos Santos,Adriana Sotero-Martins \\ ${ }^{124}$ Department of sanitation and environmental health, National School of Public Health Sergio Arouca - \\ Oswaldo Cruz Foundation \\ ${ }^{3}$ Scientific Computing Program, Oswaldo Cruz Institute - Oswaldo Cruz Foundation
}

\begin{abstract}
-
The sanitary quality of water was evaluated in two micro basins, Bacaxá and Capivari belonging to the Lakes Basin São João in the state of Rio de Janeiro, Brazil, for colimetric and parasitological analysis. Analyses were performed seasonally over a year and the levels of Escherichia coli were within the recommended only in the summer of 2012 and fall, and inappropriate with levels above recommended in winter, spring and summer of 2013 in both the micro basins. Through our observations, we compare the average values of the levels of total coliforms and Escherichia coli between both rivers. Initially, the samples indicate a similarity between the distributions of coliforms and Escherichia coli. However, Mann-Whitney-Wilcoxon test samples indicate that the distributions are different. In parasitological analysis it was observed that in Capivari was detected a greater presence of filarial larvae. Anthropogenic influences mainly by the presence of sewage is being able to compromise the health quality of the micro basins studied carrying a significant pollutant load to the Juturnaíba reservoir. The monitoring of the sanitary quality of the watersheds that supply the population may indicate when it is necessary to adopt more effective measures in the treatment of water supply of cities.
\end{abstract}

Keywords: sanitation, water quality, fecal coliforms, parasitological analysis.

\section{INTRODUCTION}

The micro basins of the rivers Capivari and Bacaxá belonging to Lakes Basin St. John, are located in the municipalities of Silva Jardim and Rio Bonito in the state of Rio de Janeiro - Brazil. Together these micro basins supply the Juturnaíba reservoir that delivers fresh water to all municipalities of the coastal zone of the lake region, the extent of the Saquarema aBuzios. Despite the important contribution of the water in the reservoir, these micro basins suffer from polluting activities in their surroundings, such as garbage dumps, grazing areas, urban areas, mining activities and activities of licensed enterprises with high pollution impact. In addition, the region has in its history the exploitation of minerals, occupation for timber, crops with sugar cane cultivation, cereal, coffee and as in cities across the world, population growth on the banks of rivers(1). These activities contribute to the destruction of springs, vegetation and soil, decreased fauna, water turbidity, silting of rivers, destruction of dunes and archaeological sites, erosion and consequently the landscape mischaracterization and environmental degradation(2).

In addition to environmental degradation, pollution of water bodies originating from human activities is affecting human and animal health, spreading diseases that threaten the health of populations. Freshwater sources used by humans through wells, rivers, streams and lakes, suffering an ongoing and increasing process of degradation due to the dumping of sewage in natura or processed, of animal feces (wild and production), and of waste arising from industrial activities. So waterborne diseases of bacterial origin and mainly of parasitological origin caused by intestinal protozoa always been one of the major public health problems(3).

Several parasites are transmitted by waterborne through water containing cysts or via food contaminated by these waters. Among them is the Ascarislumbricoides, Giardia lamblia, Entamoeba histolytica, Cryptosporidium, Toxocara sp. (4), causing worm infections and gastrointestinal diseases. Diarrhoea is a common symptom of gastrointestinal infection and according to the UN and the UNICEF report (2010), this is the second cause of infant mortality in the world(5)and the main reason is undoubtedly water contaminated by viruses, bacteria and protozoa trailers with poor hygienic conditions.

Among the bacteria, fecal bacterial indicators such as E. coli, Fecal Coliform and Enterococcus spp.They are internationally used as biological indicators of pollution (6) and Brazil are recommended by law 
the National Environmental Council - CONAMA nr. 274(7), as water quality indicators for bathing and Decree nr. 2,914(8) for potability. In Brazil, there is the law specified for the assessment of water quality need for parasitological analysis and virus pollution indicators, only recommended in the 5th paragraph of Article 2(7)the research of pathogenic organism recreation waters deemed inappropriate.

Believing that the water quality of the rivers reflect the health conditions of cities and presents a diagnosis of the environmental health of these ecosystems, the objective of this study was to evaluate the sanitary quality of water of the rivers Capivari and Bacaxá, in the region of Lakes- RJ. Through colimetric and parasitological analysis we seek to contribute to the studies of water monitoring, as well as being a preliminary study for parasitological analysis of these environmental matrices in the region and provide data for the development of appropriate strategies for remediation, monitoring and recovery of the body of Water.

\subsection{Samplecollection}

\section{METHODS}

The collection points were set after conducting a campaign "sample pilot", being this collection valued at least 3 points in each river: one at the beginning (amount), another in the middle and one at the end (downstream). The samples were collected seasonally starting in the summer of 2012 and be completed in the summer of 2013, completing a year of monitoring.

Frame1.Location of collection points

\begin{tabular}{|c|l|c|c|c|}
\hline Points & \multicolumn{1}{|c|}{ Location } & Initials & Latitude & Longitude \\
\hline \multirow{3}{*}{$\begin{array}{c}\text { River } \\
\text { Bacaxá }\end{array}$} & Start Bacaxá - Source (private property); & S-B & $22^{\circ} 37^{\prime} 52.6$ & $42^{\circ} 34^{\prime} 40.8$ \\
\cline { 2 - 5 } & MediumBacaxá - Haras (near Lavrascommunity); & M-B & $22^{\circ} 40^{\prime} 13.2$ & $42^{\circ} 34^{\prime} 50.5$ \\
\cline { 2 - 6 } & End Bacaxá - Bridge of wasps; & E-B & $22^{\circ} 42^{\prime} 43.1$ & $42^{\circ} 21^{\prime} 36.0$ \\
\hline River & StartCapivari - Beside the University UNIGRANRIO*; & S-C & $22^{\circ} 38^{\prime} 24.66$ & $42^{\circ} 28^{\prime} 14.92$ \\
\cline { 2 - 6 } Capivari & End Capivari - near the mini treatment plant CEDAE**. & E-C & $22^{\circ} 38^{\prime} 33.77$ & $42^{\circ} 24^{\prime} 0.85$ \\
\hline
\end{tabular}

*University of the Great Rio (Rio de Janeiro), Silva Jardim fields

** State Company for Water and Sewers of Rio de Janeiro

\subsection{Colimetricassays}

$50 \mathrm{ml}$ of water were collected in sterile tubes, followed by packing into Styrofoam box and kept under refrigeration until the arrival in the laboratory. The analysis of the levels of Total Coliforms (TC) and Escherichia coli were performed by the membrane filter method described in Standard Methods for the Examination of the Water and Wasterwater(9).For the isolation of the microorganisms used was the methodology described in the Merck Manual (2000), using display means of chromogenic cultureChromocult ${ }^{\circledR}$ Coliform Agar (Cat. No. 1.10426.0100/500).pre-established dilutions were made in sampling pilot considered the degree of pollution impact. A volume of $10 \mathrm{ml}$ of the diluted filtrate was estercelulose through a membrane of $47 \mathrm{~mm}$ in which the microorganisms were retained. After filtration the membrane was placed on the middle ChromoCult, and growth of colonies was observed after $24 \mathrm{~h}$ at $37^{\circ} \mathrm{C}$. The result of the number of colonies counted was multiplied by the dilution factor. Eachdilutionwasdone in triplicate.

The data count of colonies presumed to be total or fecal coliforms (thermotolerant) were used to evaluate the sanitary conditions of water based on the study of Amaral and colleagues (2012)(10). The values were expressed as colony forming units (CFU) per 100 milliliters. The reference values that have been used here for comparison purposes as the own levels and improper the primary contact waters subject to use for bathing were described in CONAMA Resolution No. 274/2000(7)which defines how excellent parameter 200 Escherichia coli(EC) per 100 milliliters (MPN /100ml). However as the evaluation test of colimétricos levels used in this study produces results as CFU / $\mathrm{mL}$, used in this way for the conversion of NMP CFU taking into account the data described by Gronewold and Wolpert (2008)(11). Used as the reference parameter great converted to CFU 92.30 appears as Escherichia coli per $100 \mathrm{ml}$ (UFC / 100mL). In order to better graphical visualization, this value was calculated limits in log base 10 It follows $1.965202 \mathrm{CFU} / 100 \mathrm{~mL}$ for Escherichia coli about.

\subsection{Mann-Whitney-Wilcoxon test}

The Mann-Whitney-Wilcoxon (M-W-W) is a non-parametric test, alternative to the Student test to compare the means of two independent samples. The only assumption required for the application of W-W-M test is that the two samples are independent and random, and that the variables are numerical or ordinal analysis. In this test given two samples of size N1 and N2, the null hypothesis states that the two samples have the same distribution, and if it does, the average (and median) of the two samples are equal. The test can also be expressed in comparison with the median:

$$
H_{0}: \tilde{\mu}_{1}=\tilde{\mu}_{2} H_{1}: \tilde{\mu}_{1} \neq \tilde{\mu}_{2}
$$


The completion of the test is made by combining the observations of the two samples on a single variable N1 + N2 size, identified their sources. Then the set of observations thus formed by the junction of the two samples is sorted in ascending order, assigning the order number 1 to the lower observation and the order number N1 + N2 to further observation. If there is "draws" or "ties" to each observation "tied" is assigned the number of middle order that these observations would have if they were not "tied". Subsequently, we calculate the sums of the serial numbers of the observations of each sample, W1 and W2, for the elements of the N1 and N2 samples, respectively. From W1 and W2, calculate the quantities:

$$
\begin{aligned}
& U_{1}=N_{1} \cdot N_{2}+\frac{N_{2} \cdot\left(N_{2}+1\right)}{2}-W_{2} \\
& U_{2}=N_{1} \cdot N_{2}+\frac{N_{1} \cdot\left(N_{1}+1\right)}{2}-W_{1}
\end{aligned}
$$

Finally, the test statistic is given by:

$$
U=\min \left(U_{1}, U_{2}\right)
$$

If both the test samples have the same size or greater than 10 observations, can make up the approximation to the normal distribution function with parameters:

Expected value:

$$
\mu_{U}=\frac{N_{1} \cdot N_{2}}{2}
$$

Variance:

$$
\sigma_{U}^{2}=\frac{N_{1} \cdot N_{2}\left(N_{1}+N_{2}+1\right)}{12}
$$

If there are "draws" or "ties" in order numbers, must be a correction in the calculation of the variance; ui being the numbers of the serial numbers "tied", the expression for calculating the variance should be:

$$
\sigma_{U}^{2}=\frac{N_{1} \cdot N_{2}}{12} \times \frac{N^{3}-N-\sum\left(u_{i}^{3}-u_{i}\right)}{N^{2}-N}
$$

The test statistic is:

$$
Z=\frac{U-\mu_{U}}{\sqrt{\sigma_{U}^{2}}}
$$

\subsection{Parasitological analysis}

For retention and detection of parasites in water forms commercial filter was used Wind Micro® blanket and rewound wire porosity of $1 \mu \mathrm{m}(12,13)$ coupled to pipe motor pump output. The filtration time was 20 minutes determined according to the flow, so that the cartridge pass 2000 liters of water. The material retained on the filter was removed after disassembly thereof by washing with 1 liter Tween 80 solution $1 \%$. The fluid was placed in sedimentation cup and of the resulting sediment was preserved in SAF for further analysis by Lutz parasitological method(14).

\subsection{Weather conditions}

\section{Results}

Frame 1 described below, is the meteorological parameters on collection day. data from two previous days were considered the collection, the precipitation of rain parameter because this directly influences the volume of water present in rivers and can change the quality of samples: more diluted samples in rainy or more concentrated days in case of consecutive days rainless with high incidence of the sun.

Frame 1-weather conditions in the days of sample collection

\begin{tabular}{|l|c|c|c|c|}
\hline \multicolumn{1}{|c|}{ Seasons } & Rainfall showers $\left(\mathrm{mm}^{3}\right)$ & Temp.Máxim $\left({ }^{\circ} \mathrm{C}\right)$ & Temp.Mínimum $\left({ }^{\circ} \mathrm{C}\right)$ & Relative humidityAverage $(\%)$ \\
\hline Summer 2012 & $* 0.8$ & 38.2 & 24.4 & 68.75 \\
\hline Autumn 2012 & $* 0$ & 26.6 & 19 & 79.25 \\
\hline Winter 2012 & 1.9 & 30 & 17 & 78.75 \\
\hline Spring2012 & $* 0$ & 31.5 & 24.7 & 66.5 \\
\hline Summer 2013 & $* 0.6$ & 31.1 & 31.1 & 66.75 \\
\hline
\end{tabular}


Source: National Institute of Meteorology - INMET, accessed in 2014. * Referstorainfallprecipitation data prior tocollection.

Coincidentally, in the days before the collection, there was no representative levels of rainfall that would influence changes in data levels in the samples. The stations with the highest levels of temperature were the summer of 2013 and spring of 2013, followed by the summer of 2012 . The winter was the coldest season, then fall.

\subsection{Resultscolimetric assays}

In summer 2012, all the collection points were presented with the prescribed by law for the EC levels. We highlight the EC level of I-B point that despite being in recommended levels, presents high because it is a spring, indicating fecal contamination probably be a breeding fish above this point (Figure 1). The M-B point was not collected in this campaign. In the fall, all presented points are within the recommended limits in the legislation to EC. In autumn and winter the point I-B presented - is lower compared to summer 2012 and within the recommended (Figure 1). In the F-spring and summer point C 2013 B-F showed point well below the threshold, indicating that there was a dilution water in the course of these rivers. The other points in the winter, spring and summer 2013 presented above the recommended limit for EC indicating fecal contamination, as well as all points on all campaigns showed high levels for TC indicating the presence of organic matter in general decomposition (Figure 1).
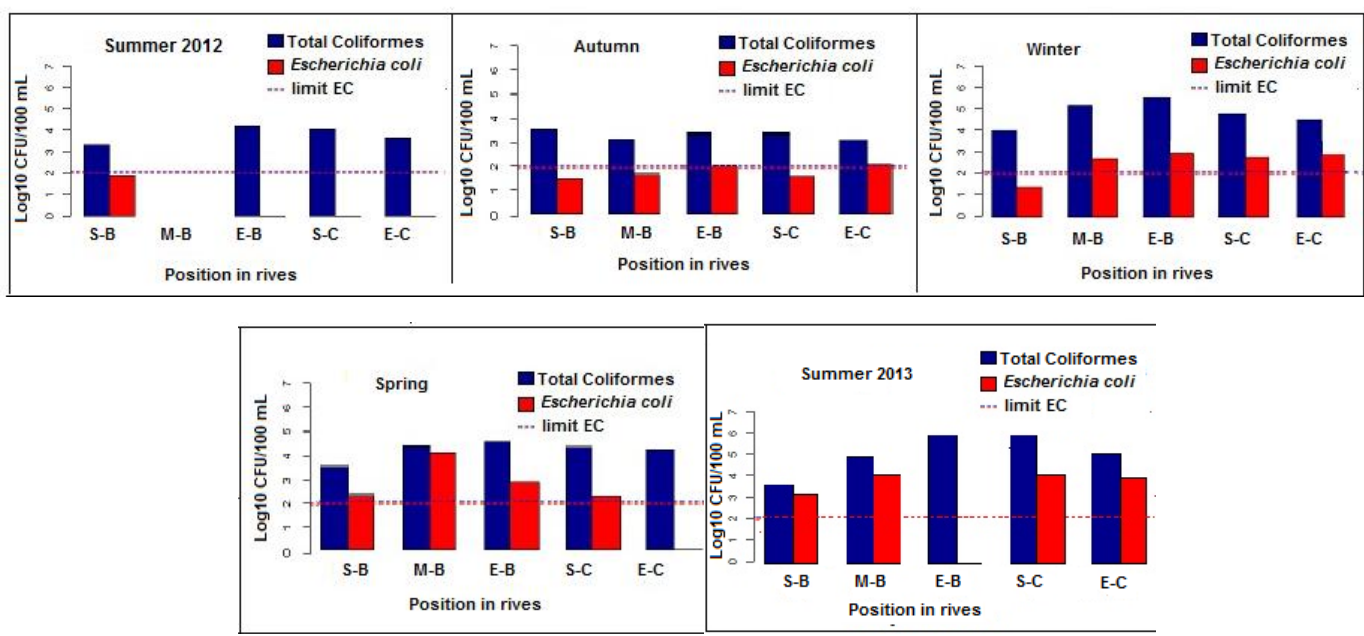

Figure 1.Colimetric assays results(S-B start Bacaxá; $M-B=$ Mean Bacaxá; $E-B=$ End Bacaxá; $S-C=$ Start Capivari; E-C = End Capivari.

Assessing the average of the Bacaxá River contamination levels seasonally, at the level of E. coli the river presented itself recreation in summer and fall (Figure 2). In winter and spring showed EC levels above recommended, indicating the presence of biological pollution. Assessing the average EC River Capivari's levels in the summer recreation presented itself and from the fall and can observe the presence of polluting activities, which may have led to increased level of $E$. coli, and which decreases in interval between winter and spring, but had a progressive increase in this season, reaching E.coli level higher than the TC at the end of the season.

Average for season of the year

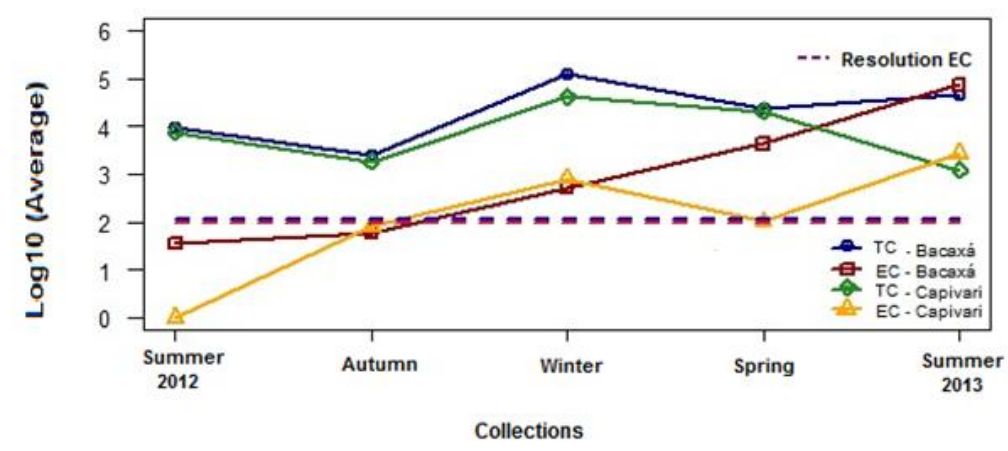

Figure 2.Average coliform levels for season 
Analyzing the distribution of TC and EC reading data to riverBacaxá, we observe variability similar between the two readings (Figure 3). However, 50\% of EC reading values lie near the lowest TC value reading. In contrast, $50 \%$ of the TC read values are above the highest reading value EC. For data of riverCapivari data distribution was wide variation between TC scan data, where outliers were detected (Figure 4). However, EC reading values for Capivari's river, kept below a distribution observed for EC reading.
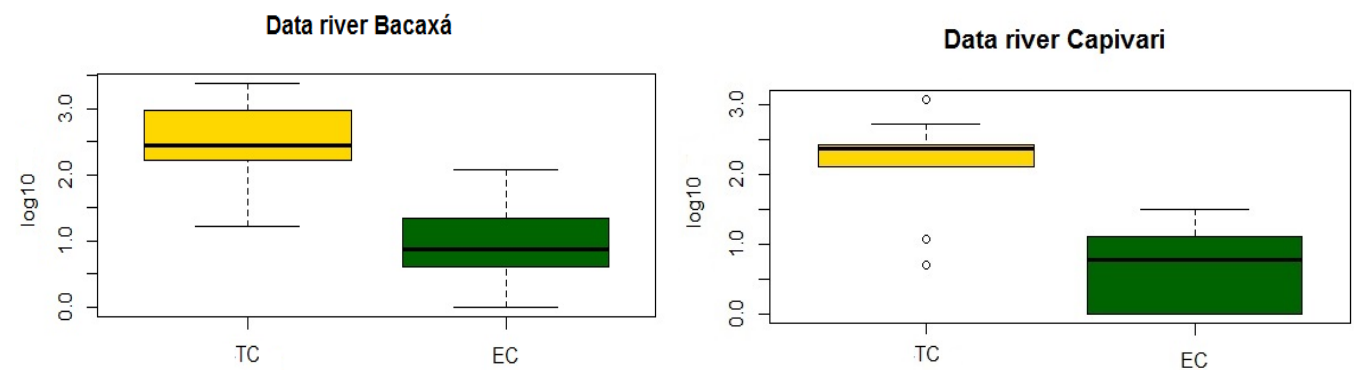

Figure 3.Boxplot riverBacaxáFigure 4. Boxplotriver Capivari

\subsection{Comparison of distributions applying the Mann-Whitney-Wilcoxon test}

We applied the Mann-Whitney-Wilcoxon test, non-parametric alternative test to the Student test to compare the means of two independent samples. Considering N1 and N2 sizes of the two samples (river Bacaxá and Capivari), the hypothesis test was:

$\mathrm{H}_{0}$ : The two samples have identical distributions

$\mathrm{H}_{1}$ : The two samples have different distributions

The null hypothesis states that two samples have the same distribution, and thus, both the average as the median of the two samples are equal.

$$
H_{0}: \tilde{\mu}_{1}=\tilde{\mu}_{2} H_{1}: \tilde{\mu}_{1} \neq \tilde{\mu}_{2}
$$

We calculate the test statistic $U$ as follows: there was the two samples combined into a single 10 size variable that was organized in ascending order. Assigning the order number 1 to the lower observation and the order number N1 + N2 to further observation. In case of ties, each of the observations "tied" was assigned the number average order that these observations would have if they were not "tied".

\begin{tabular}{|c|c|}
\hline \multicolumn{2}{|c|}{ Rives (Bacaxá e Capivari) } \\
\hline Reading TC & Reading EC \\
\hline 136 & 56 \\
\hline 166 & 30 \\
\hline 1215 & 0 \\
\hline 1215 & 31 \\
\hline 244 & 23 \\
\hline $\mathrm{N}_{1}=5$ & $\mathrm{~N}_{2}=5$ \\
\hline
\end{tabular}

\begin{tabular}{|c|c|c|c|}
\hline & OrderTC & Order EC & Calculation for Draws \\
\hline 0 & & 1 & \\
\hline 23 & & 2 & \\
\hline 30 & & 3 & \\
\hline 31 & & 4 & \\
\hline 56 & & 5 & \\
\hline 136 & $\mathbf{6}$ & & \\
\hline 166 & $\mathbf{7}$ & & $\frac{(9+10)}{2}=9,5$ \\
\hline 244 & $\mathbf{8}$ & & \\
\hline 1215 & $\mathbf{9 , 5}$ & & \\
\hline 1215 & $\mathbf{9 , 5}$ & & \\
\hline
\end{tabular}

Where the sum of the serial numbers of observations of sample 1 and 2 are $\mathrm{W}_{1}=40$ e $\mathrm{W}_{2}=15$, , respectively. Thus, the quantities $U_{1}=25$ e $U_{2}=0$. Therefore, the test statistic $U=\min \left(U_{1}, U_{2}\right)$ was equal to zero. For a level of significance $\alpha=5 \%$, e $\mathrm{N}_{1}=5$ e $\mathrm{N}_{2}=5$, the critical quartile of the distribution Mann-WhitneyWilcoxon is $U_{(0,05 ; 5 ; 5)}=2$ (checked in the critical test table $U$ ), and as the test statistic $U=0$ is less than this critical value, it must reject the null hypothesis that the two samples have the same distribution. 
The Wilcoxon test of rivers presented similar value. That is, reject the hypothesis H0 that the distributions, mean and median are equal. We calculated the Pearson correlation value of all CT values with all EC values. The value was very low, showing no correlation between them.

\subsection{Results Parasitological}

The table below describes the occurrence of parasites detected seasonally. According to Table 1, were detected parasites as follows: during the collections in the fall, longer period of detection, parasites were found on three collection points; followed by the spring, which were found at both sites; in other companhas, summer 2012, winter and summer 2013 were found parasites in just one collection point. Since the point I-C showed the more positive times in 3 consecutive campaigns, only in spring 2012 and summer of 2013 did not.

Table 1.Parasitological results in different points of seasonally collection.

\begin{tabular}{c|c|c|c|c|c}
\hline $\begin{array}{c}\text { Season } \\
\text { Points }\end{array}$ & Summer 2012 & Autumn & Winter & Spring & Summer 2013 \\
\hline S-B & Negative & $\begin{array}{c}\text { FilarialLarvae } \\
\text { comp. 130X8 }\end{array}$ & Negative & Negative & Negative \\
\hline M-B & - & Negative & Negative & $\begin{array}{c}\text { FilarialLarvae comp. } \\
240 X 10 / 240 X 10 / \\
270 X 12 / 320 X 10\end{array}$ & $\begin{array}{c}\text { FilarialLarvae } \\
\text { comp. 364X12/ } \\
168 X 8\end{array}$ \\
\hline E-B & Negative & $\begin{array}{c}\text { FilarialLarvae } \\
\text { comp. 340X10 }\end{array}$ & Negative & $\begin{array}{c}\text { FilarialLarvae comp. } \\
\text { 300X14/ } \\
\text { eggascarideotoxocara } \\
40 X 30\end{array}$ & Negative \\
\hline S-C & $\begin{array}{c}\text { FilarialLarvae } \\
\text { comp. 236X10 } \\
1122 X 6 / 250 X 10\end{array}$ & $\begin{array}{c}\text { FilarialLarvae } \\
\text { comp. 300X14 }\end{array}$ & $\begin{array}{c}\text { FilarialLarvae comp. } \\
480 X 10 / 300 X 8 / \\
270 X 12 / 380 X 6\end{array}$ & Negative & Negative \\
\hline E-C & Negative & Negative & Negative & Negative & Negative \\
\hline
\end{tabular}

In the summer, was detected at the point S-C lavas filarial and M-B (Average Bacaxá) was not collected. In the fall, lavas filarial were detected in S-B, E-B and S-C; in winter, filarial larvae were detected in section S-C; in the spring, filarial larvae were detected in the M-B and E-B points and in the summer of 2013, closing the monitoring, filarial larvae were detected in the M-B point. Thus, we can see the total of collected samples that $33 \%$ of samples were positive for parasites in Bacaxáriver, while $30 \%$ were positive for the parasite in Capivari river.

\section{Discussion}

The evaluation of water quality has been carried out in accordance with the stipulated standards colimétricos (CONAMA 274/2000), quantifying the presence of E. coli and fecal coliforms. However, the research of parasites and viruses, important indicators of fecal contamination, are not recommended by legislation. According McQuaig classical microbiology conventional techniques linked to molecular techniques offer a more comprehensive and representative parameter water quality including allowing research the sources of pollution (15)be bacteriological, viral or protozoal, human sources or not.

The high density of human population and the provision of treated sewage does not suggest to be the main source contributing to the high concentrations of fecal indicator bacteria in water samples (16).The presence of fecal microorganisms in water indicates fecal pollution and possible association with enteric pathogens(17).

This work addressed the assessment of water quality of the micro basins Capivari and Bacaxá, major rivers that carry pollutants into the reservoir Juturnaíba for microbiological and parasitological analyzes. We used as comparison criteria to CONAMA resolution 274/2000 (7)that defines how great the 200 E. coli per 100 milliliters limit and considers improper when sampling If present above $2000 \mathrm{E}$. coli per 100 milliliters. In colimétricos testing periods had higher levels of $E$. coli were in the spring and summer of 2013 with 10,500 values and 45,000 CFU /100 ml respectively.

We also note that the average E. coli and TC levels in Bacaxá river was higher than in the Capivaririver, which is the main polluter of Juturnaíba Dam. Despite the pollution potential of these rivers, compared to Griffith work and colleagues (2009)(18)which detected concentrations in the vicinity of 580 to> 200,000 CFU / $100 \mathrm{~mL}$ on the beaches of California with influences of sewage and Bower and colleagues (2005)(19)that detected levels around 11500-20000 CFU / 100mL E. coli in the rivers that flow into Lake Michigan, so our samples showed polluters microorganisms concentrations well below.

In the parasitological test we can observe the involvement of about $30 \%$ each by parasitological river contamination. Corroborating our work, study Handam and colleagues (2015)(20)It was detected about 25 larvae, 15 helminth eggs and 2 oocysts of protozoa in five sampling points of water samples in the Manguinhos complex - RJ, an environment that receives effluents without any treatment directly into their water bodies. 
waterborne protozoa represent a major public health problem by the environmental persistence and resistance to chlorination constituting risks of acquiring these in recreation waters(3). This scenario is also worrying for primary contact environments such as sand and fields where the risk of contracting parasites is extremely high. In the study of Amaral and colleagues (2012)(10)who researched the incidence of parasites in beach sand, found 39 positive samples in winter, 29 in spring, 33 in summer and 38 in the fall, and the presence of animals in these environments, as well as the presence of determinants pollutants for this type of contamination.

\section{Conclusion}

The human influence is being able to compromise the health quality of the micro basins studied, and in some periods (summer 2012 and fall) climatic factors and the maintenance of the ecosystem itself can contribute to observation of fecal coliform values within the normal range for balneáveis waters. However, this work highlights the need for monitoring of the main micro basins that provide water to the reservoir that supplies cities.

\section{Acknowledgment}

We thank ConsórcioIntermunicipal Lagos São João by the present proposal and the Education Group for the Environment (GEMA) for institutional support. We also thank the Parasitology Laboratory Technicians of the National Public Health School - FIOCRUZ, Luiz Carlos Pina and Nilton Francisco da Conceição, fundamental parts of our work, for helping us in the collections and parasitological analysis, our love and thanks.

\section{Referências}

[1]. Consócio Intermunicipal Lagos são João. SaoJoao. 2003. p. 178

[2]. Proposed Environmental Zoning of Guanabara Bay. Available from: http://www.anuario.igeo.ufrj.br/anuario_2003/anuario_igeo_2003_claudio.pdf

[3]. Franco R. Waterborne Protozoa : relevance in public health. Rev Panam Infectol. 2007;9(4):36-43.

[4]. Neves DP, Gomes CFL, Iglésias JJF, Barçante JM de P, Santos R la C dos. Parasitology Dinamica. $3^{\circ}$ Edição. São Paulo: Atheneu; 2009. $592 \mathrm{p}$.

[5]. Wardlaw T, Salama P, Brocklehurst C, Chopra M, Mason E. Diarrhoea: why children are still dying and what can be done. The Lancet. 2010. 870-872 p

[6]. SOTERO-MARTINS, A; DUARTE A, CARVAJAL E, SARQUIS M, FERNANDES O. Control of microbiological and parasitic quality recreation areas. Rev Electronic Health Management. 2013;v. 4, n. 3

[7]. Brazil. NATIONAL COUNCIL OF ENVIRONMENT-CONAMA MIDDLE -Resolution nr. 274/2000. Brasilia: Official Gazette of the Federative Republic of Brazil; 2001. p. 70-1.

[8]. Brazil. Ministry of Health - Order nr. 2,914 / 2011. Brasilia;2011.

[9]. Eaton AD, Clescerl LS, Rice EW, Greenberg AE, Franson MA. Standard Methods for the Examination of Water and Wastewater, 21st Edition. 21st Editi. American Water Works Association. New York: American Water Works Association; 2005.1368 p.

[10]. Amaral LS, Martins AS. Parasites monitoring and coliforms as Health Assessment Standards of Sand and Guanabara Bay Beaches Water. [Rio de Janeiro, Brazil]: Oswaldo Cruz Foundation; 2012.

[11]. Gronewold AD, Wolpert. RL. Modeling the relationship between most probable number (MPN) and colony-forming unit (CFU) estimates of fecal coliform concentration. Water Res. 2008;42:3327-34.

[12]. Kaucner C, Stinear T. Sensitive and rapid detection of Giardia cysts and Cryptosporidium parvum oocysts in large - volume water samples with woundfiberglass cartridge filters an reverse transcription - PCR. Appl Enviromental Microbiol. 1998;64 (5):1743-9.

[13]. FG., Laurentino-silva V., Gaspar A., Ramos GDM. research of parasites in the water consumed by

[14]. Sana District population - Macaé - Rio de Janeiro. HigAliment.2007;21:345-6.

[15]. AMARAL L, DUARTE A, SILVA V, PINNA L, SOTERO-MARTINS. Parasitological indicators of contamination at sand of beach and monitoring by traditional methods and immunoenzymatic assay. Brazilian J Biosyst Eng. 2015;9 , n 4:304-11.

[16]. McQuaig S, Griffith J, Harwood VJ. Association of fecal indicator bacteria with human viruses and microbial source tracking markers at coastal beaches impacted by nonpoint source pollution. Appl Environ Microbiol. 2012;78(18):6423-32

[17]. Kishinhi SS, Tchounwou PB, Farah IO. Molecular Approach to Microbiological Examination of Water Quality in the Grand Bay National Estuarine Research Reserve (NERR) in Mississippi, USA. Environ Health Insights. 2013;7:33-41.

[18]. Sinigalliano CD, Fleisher JM, Gidley ML, Solo-Gabriele HM, Shibata T, Plano LRW, et al. Traditional and molecular analyses for fecal indicator bacteria in non-point source subtropical recreational marine waters. Water Res. 2010;44(13):3763-72.

[19]. Griffith JF, Cao Y, McGee CD, Weisberg SB. Evaluation of rapid methods and novel indicators for assessing microbiological beach water quality. Water Res. 2009;43(19):4900-7.

[20]. Bower PA, Scopel CO, Jensen ET, Depas MM, McLellan SL. Detection of Genetic Markers of Fecal Indicator Bacteria in Lake Michigan and Determination of Their Relationship to Escherichia coli Densities Using Standard Micobiological Methods. Appl Environ Microbiol. 2005;71(12):8305-13.

[21]. Handam NB, Sotero-Martins. of Residential Water Sanitary Conditions, Soil peridomiciliary and Rivers of the Residential Water Sanitary Conditions, Soil peridomiciliary and Rivers of Sanitary Conditions of Residential Water, Soil peridomiciliary and Rivers of conditions Sanit. 2016. 